\title{
Synthesis and Thermal Characterization of Lanthanide(III) Complexes with Mercaptosuccinic Acid and Hydrazine as Ligands
}

\author{
S. Devipriya, ${ }^{1}$ N. Arunadevi, ${ }^{2}$ and S. Vairam ${ }^{1}$ \\ ${ }^{1}$ Department of Chemistry, Government College of Technology, Coimbatore 641013, India \\ ${ }^{2}$ Department of Chemistry, SNS College of Technology, Coimbatore 641035, India \\ Correspondence should be addressed to S. Vairam; vamshen@yahoo.com
}

Received 27 January 2012; Revised 11 July 2012; Accepted 12 July 2012

Academic Editor: Marc Visseaux

Copyright (c) 2013 S. Devipriya et al. This is an open access article distributed under the Creative Commons Attribution License, which permits unrestricted use, distribution, and reproduction in any medium, provided the original work is properly cited.

\begin{abstract}
Reaction of hydrazine and mercaptosuccinic acid with metal ions forms complexes with general formula $\left[\operatorname{Ln}\left(\mathrm{N}_{2} \mathrm{H}_{4}\right)_{2}\right.$ $\left.\left\{\mathrm{CH}_{2}(\mathrm{COO}) \mathrm{CH}(\mathrm{SH})(\mathrm{COO})\right\}_{1.5}\right] \cdot\left(\mathrm{H}_{2} \mathrm{O}\right)$, where $\mathrm{Ln}=\mathrm{La}(\mathrm{III}), \mathrm{Pr}(\mathrm{III}), \mathrm{Nd}(\mathrm{III}), \mathrm{Sm}(\mathrm{III})$, and $\mathrm{Gd}(\mathrm{III})$ at pH 5. The complexes have been characterized by elemental analysis, IR and UV-visible spectroscopic, thermal and X-ray diffraction studies. The IR data reveal that the acid moiety in the complexes is present as dianion due to the deprotonation of $\mathrm{COOH}$ groups by lanthanides in these complexes, leaving - $\mathrm{SH}$ group unionized and hydrazine as bidental neutral ligand showing absorptions in the range of $945-948 \mathrm{~cm}^{-1}$. The thermoanalytical data evince that the complexes are stable up to $103^{\circ} \mathrm{C}$ and undergo complete decomposition in the range of $550-594^{\circ} \mathrm{C}$ resulting in metal oxides. SEM images of $\mathrm{La}_{2} \mathrm{O}_{3}$ and $\mathrm{Gd}_{2} \mathrm{O}_{3}$ residues show their nano sized clusters suggesting that the complexes may be used as precursors for nano $\mathrm{La}_{2} \mathrm{O}_{3}$ and $\mathrm{Gd}_{2} \mathrm{O}_{3}$, respectively. X-ray powder diffraction patterns show isomorphism among the complexes. The kinetic parameters of the decomposition of the complexes have been computed by Coats-Redfern equation.
\end{abstract}

\section{Introduction}

Mercaptosuccinic acid, as a ligand, has been of interest because of its versatility in coordinate modes due to two carboxylic acid and sulfhydryl groups. It is known to form complexes with divalent transition metal ions, $\mathrm{Mn}$ (II), $\mathrm{Fe}(\mathrm{II})$, $\mathrm{Co}(\mathrm{II})$, and $\mathrm{Ni}(\mathrm{II})$. It is reported that, in these complexes, $\mathrm{S}-\mathrm{H}$ is ionised and coordinated in addition to coordination of one of the $\mathrm{COOH}$ groups [1]. Patil and Krishnan have reported that alkaline earth metals $\mathrm{Mg}, \mathrm{Sr}$, and $\mathrm{Ba}$ also form $1: 1 \mathrm{com}-$ plexes in which $\mathrm{S}-\mathrm{H}$ group is not involved and two $\mathrm{COOH}$ groups involve in coordination. These complexes are found to form precipitates of metal mercaptosuccinates with aqueous solution of zinc and cadmium salts, leaving alkaline earth metal ions in solution and hence they can be used as antidote for $\mathrm{Zn}$ and $\mathrm{Cd}$ poisoning [2]. A potentiometric titration study indicates the formation of mercaptosuccinic acid complexes of $\mathrm{Zn}$ and $\mathrm{Ni}$ with and without the involvement of sulfhydryl group in coordination [3]. Another potentiometric study of chelates formed by $\mathrm{La}^{3+}, \mathrm{Ce}^{3+}, \mathrm{Pr}^{3+}$, and $\mathrm{Nd}^{3+}$ with this acid reveals that the chelates of acids containing - $\mathrm{SH}$ group are less stable than those with $\mathrm{NH}_{2}$ or $\mathrm{OH}$ donor group [4].

A study on heterochelates of $\mathrm{Zn}^{2+}$ with nitrilotriacetic acid and mercapto acids system explains the stability of chelates due to two factors, $\Pi$ interaction in $\mathrm{M}-\mathrm{S}$ bond and sigma bonding of $\mathrm{M}-\mathrm{S}$ bond due to polarisation of sulfur [5]. A similar type of study on heterochelates of $\mathrm{Ni}$ and $\mathrm{Zn}$ containing this acid and dipyridyl supports the above factors. However, it concludes that the greater stability of $\mathrm{M}-\mathrm{S}$ bond may be due to strengthening of $\mathrm{M}-\mathrm{S}$ sigma bond and the contribution of $\mathrm{M}-\mathrm{S} \Pi$ interaction, its lower stability due to the presence of coligands.

In spite of these reports, there is no systematic study of synthesis of mercaptosuccinic acid complexes with lanthanides found in the literature. We have been studying carboxylate complexes of lanthanides and transition metals using hydrazine as coligand. There are numerous reports on metal hydrazine complexes of formic [6], acetic [7], propionic [8], glycolic [9], salicylic [10], tri- and tetracarboxylic $[11,12]$, and naphthoxy and hydroxy naphthoic 
acid $[13,14]$ systems. In many complexes, hydrazine being a simple diamine acts as neutral monodentate, bidentatebridged, and monodentate $\mathrm{N}_{2} \mathrm{H}_{5}{ }^{+}$cation in many complexes $[15,16]$. With the interest of understanding the nature of interaction of lanthanides with carboxylic acid containing $\mathrm{S}-\mathrm{H}$ group and hydrazine together, we performed this work. We have reported the synthesis of new lanthanide complexes using mercaptosuccinic acid and hydrazine as ligands and their characterization by IR and UV-visible spectroscopic methods, simultaneous TG-DTA analysis, powder X-ray diffraction method, and magnetic measurements. Since these complexes were found to yield metal oxides of nanosize on decomposition, SEM image reports of residual oxides have also been presented.

\section{Experimental}

2.1. Preparation of $\left[\mathrm{Ln}\left(\mathrm{N}_{2} \mathrm{H}_{4}\right)_{2}\left\{\mathrm{CH}_{2}(\mathrm{COO}) \mathrm{CH}(\mathrm{SH})\right.\right.$ $\left.(\mathrm{COO})\}_{1.5}\right] \cdot\left(\mathrm{H}_{2} \mathrm{O}\right)$, Where $\mathrm{Ln}=\mathrm{La}(\mathrm{III}), \operatorname{Pr}(\mathrm{III}), \mathrm{Nd}(\mathrm{III})$, $S m(I I)$, and $G d(I I I)$. These complexes were prepared by adding a ligand solution which was obtained by mixing an aqueous solution of mercaptosuccinic acid $(0.3 \mathrm{~g}, 2 \mathrm{mmol}$ in $60 \mathrm{~mL}$ of $\left.\mathrm{H}_{2} \mathrm{O}\right)$ and hydrazine hydrate $(0.2 \mathrm{~g}, 4 \mathrm{mmol})$ to a metal nitrate solution which was prepared by dissolving metal oxide (e.g., $\mathrm{La}_{2} \mathrm{O}_{3}, 0.163 \mathrm{~g}, 0.5 \mathrm{mmol}$ ) in a minimum quantity of $1: 1$ conc. $\mathrm{HNO}_{3}$ and evaporated to eliminate excess of acid and dissolved in distilled water at $\mathrm{pH}$ 5. A crystalline product formed from the turbid solution while heating over water bath at $80^{\circ} \mathrm{C}$ for $1 \mathrm{~h}$ was filtered, washed with absolute alcohol followed by ether, and dried in a desiccator over anhydrous $\mathrm{CaCl}_{2}$.

2.2. Experimental Techniques. The composition was fixed by chemical analysis. Hydrazine content was determined by titrating against standard $\mathrm{KIO}_{3}\left(0.025 \mathrm{molL}^{-1}\right)$ [17]. Metal contents were determined by titrating with EDTA $\left(0.01 \mathrm{molL}^{-1}\right)$ after decomposing the complexes with $1: 1$ nitric acid [17].

IR Spectra of the complexes in the region $4000-400 \mathrm{~cm}^{-1}$ were recorded as $\mathrm{KBr}$ pellets using Perkin Elmer 597 spectrophotometer. Electronic reflectance spectra of $\operatorname{Pr}(\mathrm{III})$, $\mathrm{Nd}(\mathrm{III}), \mathrm{Sm}(\mathrm{III})$, and Gd(III) complexes were obtained using a Varian Cary 5000 recording spectrophotometer. The magnetic susceptibility of $\operatorname{Pr}($ III) and $\mathrm{Nd}$ (III) complexes was measured using a vibrating sample magnetometer, VSM EG \& $\mathrm{G}$ model 155 at room temperature. The X-ray powder diffraction patterns of the complexes were recorded using Philips X-ray diffractometer (model PW 1050/70) employing $\mathrm{Cu}-\mathrm{K} \alpha$ radiation with nickel filter. The simultaneous TGDTA experiments were carried out using SDT Q600 V8.3 instrument and Stanton 781 simultaneous thermal analyzer. Thermal analyses were carried out in air at the heating rate of $10^{\circ} \mathrm{C} / \mathrm{min}$ using 5 to $10 \mathrm{mg}$ of the samples. Platinum cups were employed as sample holders and alumina as reference. The temperature range was ambient to $800^{\circ} \mathrm{C}$. The SEM images for the final products of $\mathrm{La}(\mathrm{III})$ and $\mathrm{Gd}(\mathrm{III})$ complexes

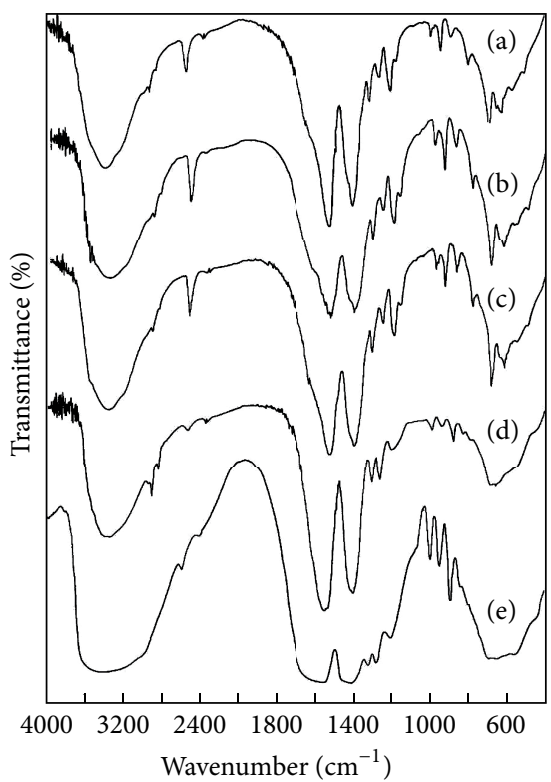

FIGURE 1: Comparison of IR spectrum of (a) $\left[\mathrm{La}\left(\mathrm{N}_{2} \mathrm{H}_{4}\right)_{2}\left\{\mathrm{CH}_{2}(\mathrm{COO}) \mathrm{CH}(\mathrm{SH})(\mathrm{COO})\right\}_{1.5}\right] \cdot\left(\mathrm{H}_{2} \mathrm{O}\right)$,

(b) $\left[\mathrm{Pr}\left(\mathrm{N}_{2} \mathrm{H}_{4}\right)_{2}\left\{\mathrm{CH}_{2}(\mathrm{COO}) \mathrm{CH}(\mathrm{SH})(\mathrm{COO})\right\}_{1.5}\right] \cdot\left(\mathrm{H}_{2} \mathrm{O}\right)$,

(c) $\left[\mathrm{Nd}\left(\mathrm{N}_{2} \mathrm{H}_{4}\right)_{2}\left\{\mathrm{CH}_{2}(\mathrm{COO}) \mathrm{CH}(\mathrm{SH})(\mathrm{COO})\right\}_{1.5}\right] \cdot\left(\mathrm{H}_{2} \mathrm{O}\right)$,

(d) $\left[\mathrm{Sm}\left(\mathrm{N}_{2} \mathrm{H}_{4}\right)_{2}\left\{\mathrm{CH}_{2}(\mathrm{COO}) \mathrm{CH}(\mathrm{SH})(\mathrm{COO})\right\}_{1.5}\right] \cdot\left(\mathrm{H}_{2} \mathrm{O}\right)$, and $(\mathrm{e})\left[\mathrm{Gd}\left(\mathrm{N}_{2} \mathrm{H}_{4}\right)_{2}\left\{\mathrm{CH}_{2}(\mathrm{COO}) \mathrm{CH}(\mathrm{SH})(\mathrm{COO})\right\}_{1.5}\right] \cdot\left(\mathrm{H}_{2} \mathrm{O}\right)$.

were recorded using a Cambridge scanning electron microscope (JEOL model JSM-6390LV) with EDX attachment (JEOL model JED-2300).

\section{Results and Discussion}

3.1. IR Spectra. IR and analytical data of the complexes are listed in Table 1. In the IR spectra of the complexes, the broad bands in the region $3333-3355 \mathrm{~cm}^{-1}$ are assigned to $v_{\mathrm{OH}}$ vibrations of the associated water molecule. The $v_{\mathrm{SH}}$ arising from sulfhydryl group which appears at $2565 \mathrm{~cm}^{-1}$ in the spectrum of pure acid was found to be shifted to lower frequencies, $2542-2555 \mathrm{~cm}^{-1}$ in case of complexes [18] implying that mercapto group is not involved in the coordination. This observation agrees with the reported values found in the literature [2]. Further this peak appears strong, clear, and sharp for $\mathrm{La}, \mathrm{Pr}$, and $\mathrm{Nd}$ complexes and weak for Sm and Gd. The hydrazine complexes display a $\mathrm{N}-\mathrm{N}$ stretching frequency in the range of $945-948 \mathrm{~cm}^{-1}$ showing bidentate bridging nature in the complexes [19]. All the complexes show absorption in the range of $1531-1556 \mathrm{~cm}^{-1}$ and $1309-1319 \mathrm{~cm}^{-1}$ corresponding to $v_{\mathrm{COO}}$ (asym) and $v_{\mathrm{COO}}(\mathrm{sym})$, respectively, and their difference being greater than $200 \mathrm{~cm}^{-1}$ corroborates monodental coordination of carboxylate group to the metal [20]. A comparison of IR spectra of lanthanide complexes is shown in Figure 1.

3.2. Thermal analysis. Thermal analysis data shown in Table 2 indicate that all complexes follow similar type of decomposition pattern confirming their similar formulation indirectly. 


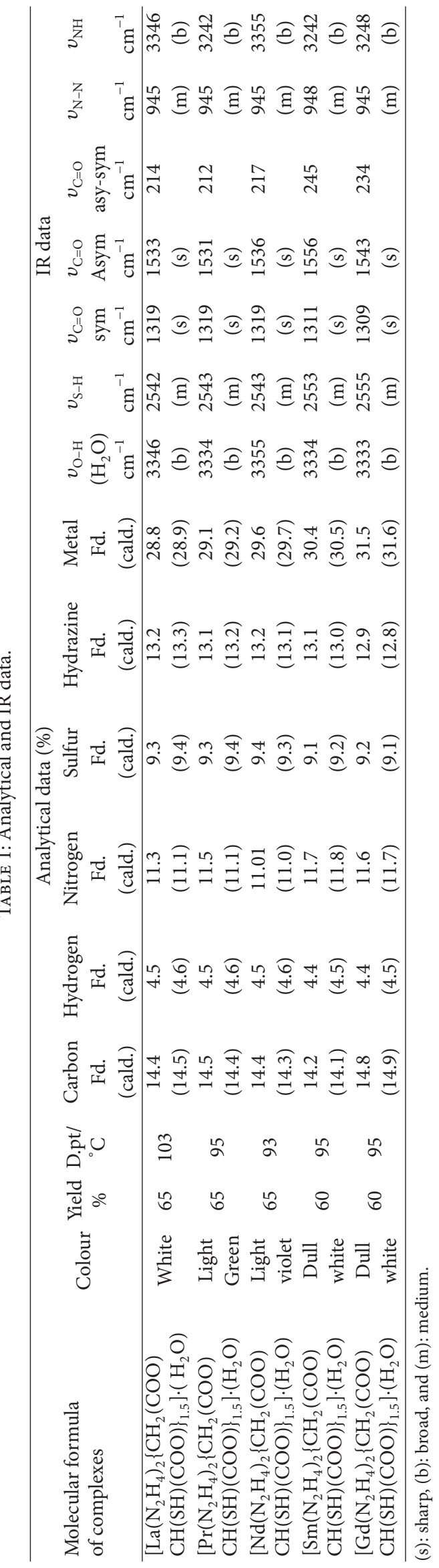




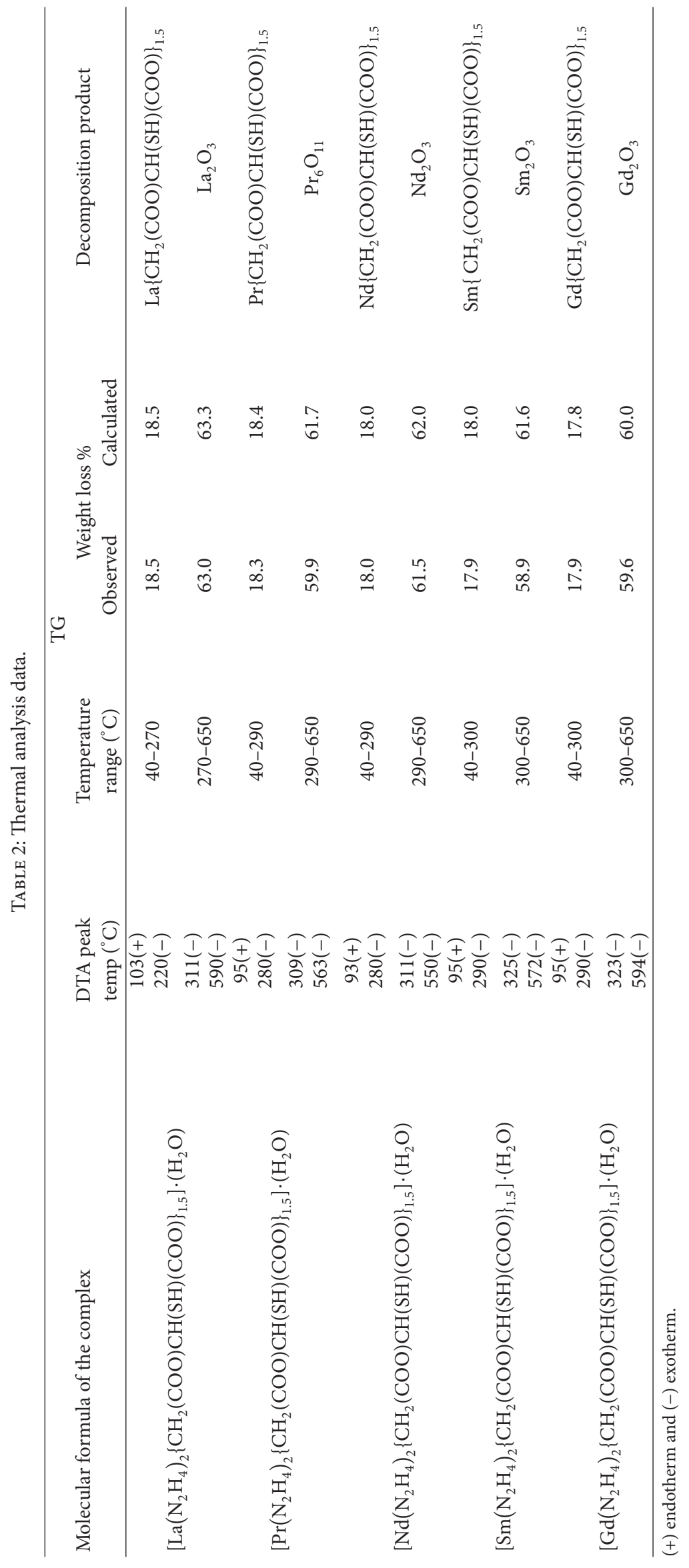


TABLE 3: Energies (in $\mathrm{cm}^{-1}$ ) of the bands of complexes.

\begin{tabular}{lcc}
\hline Molecular formula of the complexes & $\begin{array}{c}\text { Bands observed for complexes } \\
\text { (bands of aquo complexes) }\end{array}$ & Assignments \\
\hline$\left[\mathrm{Pr}\left(\mathrm{N}_{2} \mathrm{H}_{4}\right)_{2}\left\{\mathrm{CH}_{2}(\mathrm{COO}) \mathrm{CH}(\mathrm{SH})(\mathrm{COO})\right\}_{1.5}\right] \cdot\left(\mathrm{H}_{2} \mathrm{O}\right)$ & $20900(21000)$ & ${ }^{3} \mathrm{P}_{0}$ \\
& $22800(23500)$ & ${ }^{3} \mathrm{P}_{2}$ \\
{$\left[\mathrm{Nd}\left(\mathrm{N}_{2} \mathrm{H}_{4}\right)_{2}\left\{\mathrm{CH}_{2}(\mathrm{COO}) \mathrm{CH}(\mathrm{SH})(\mathrm{COO})\right\}_{1.5}\right] \cdot\left(\mathrm{H}_{2} \mathrm{O}\right)$} & $17100(17358)$ & ${ }^{4} \mathrm{G}_{5 / 2}$ \\
& $18400(19289)$ & ${ }^{4} \mathrm{G}_{7 / 2}$ \\
{$\left[\mathrm{Sm}\left(\mathrm{N}_{2} \mathrm{H}_{4}\right)_{2}\left\{\mathrm{CH}_{2}(\mathrm{COO}) \mathrm{CH}(\mathrm{SH})(\mathrm{COO})\right\}_{1.5}\right] \cdot\left(\mathrm{H}_{2} \mathrm{O}\right)$} & $17680(18200)$ & ${ }^{4} \mathrm{G}_{5 / 2}$ \\
{$\left[\mathrm{Gd}\left(\mathrm{N}_{2} \mathrm{H}_{4}\right)_{2}\left\{\mathrm{CH}_{2}(\mathrm{COO}) \mathrm{CH}(\mathrm{SH})(\mathrm{COO})\right\}_{1.5}\right] \cdot\left(\mathrm{H}_{2} \mathrm{O}\right)$} & $18700(19300)$ & ${ }^{4} \mathrm{~F}_{3 / 2}$ \\
\hline
\end{tabular}

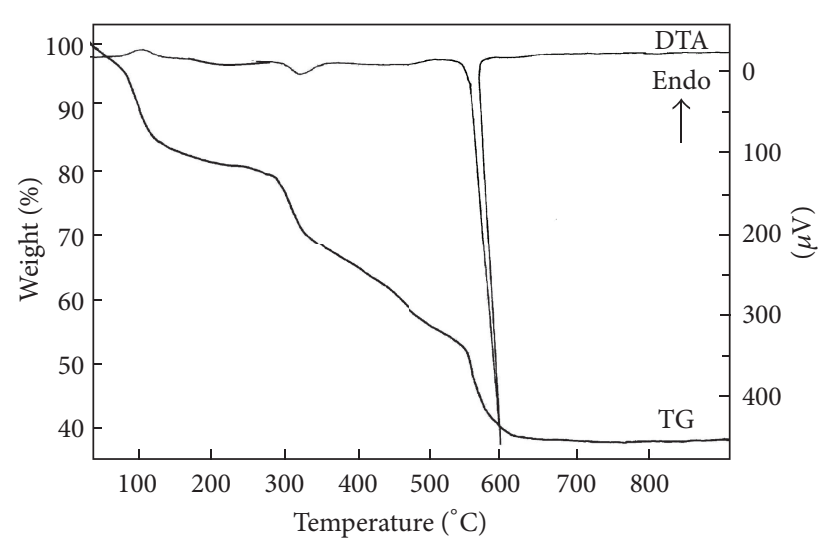

(a)

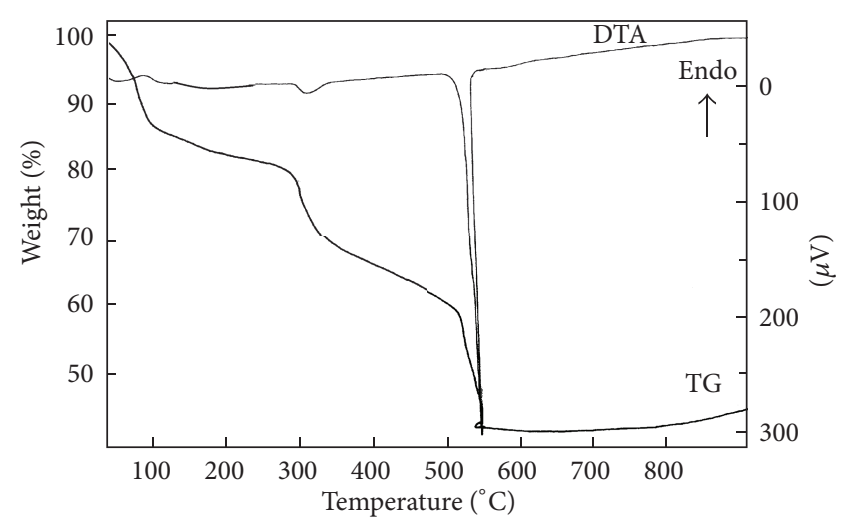

(c)

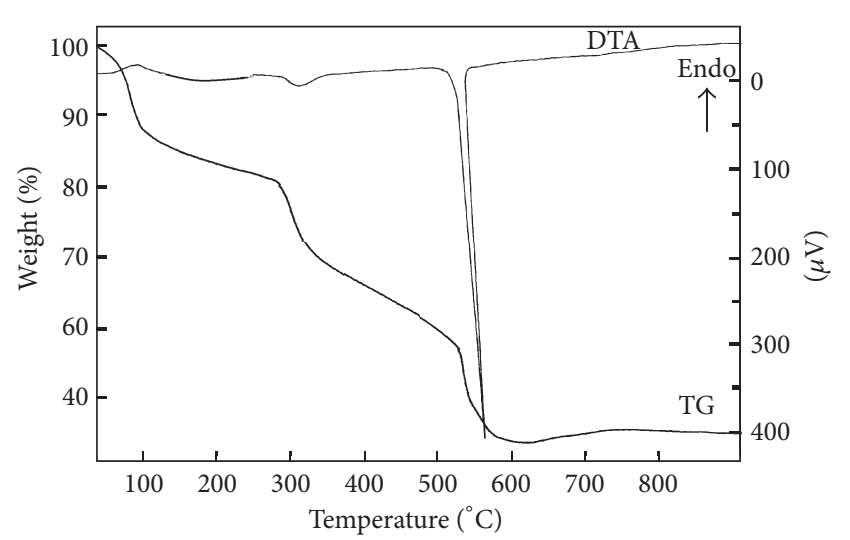

(b)

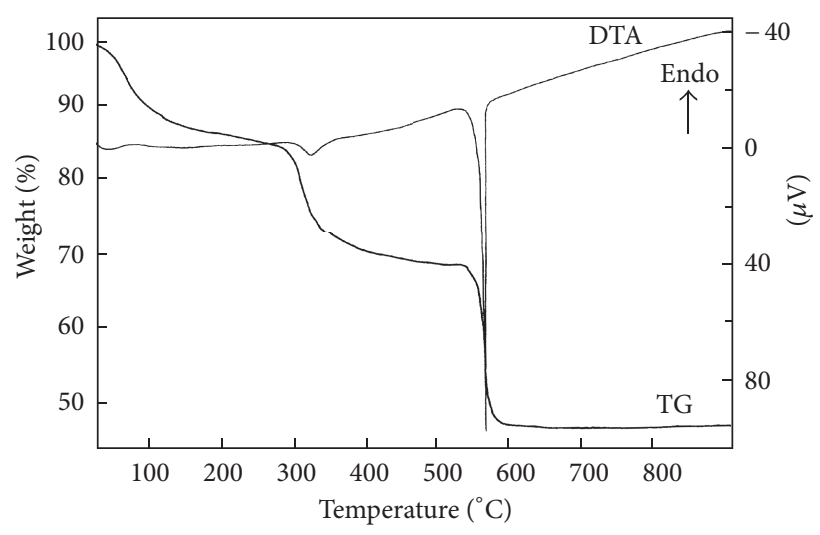

(d)

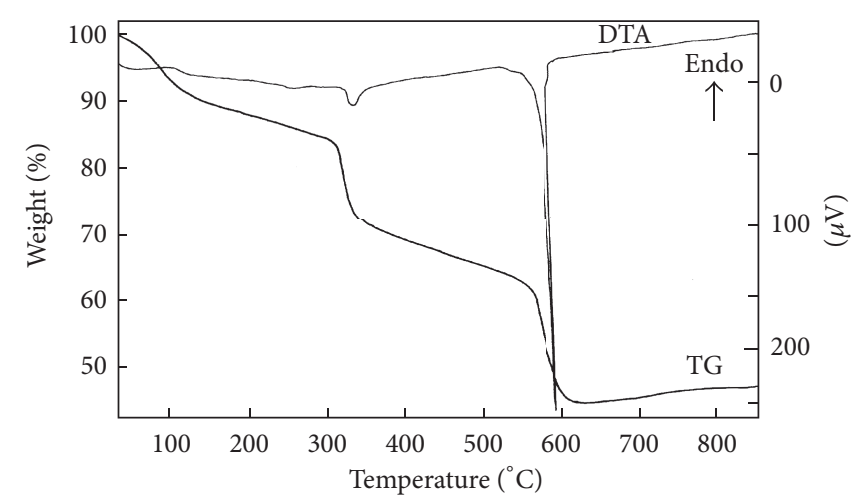

(e)

Figure 2 


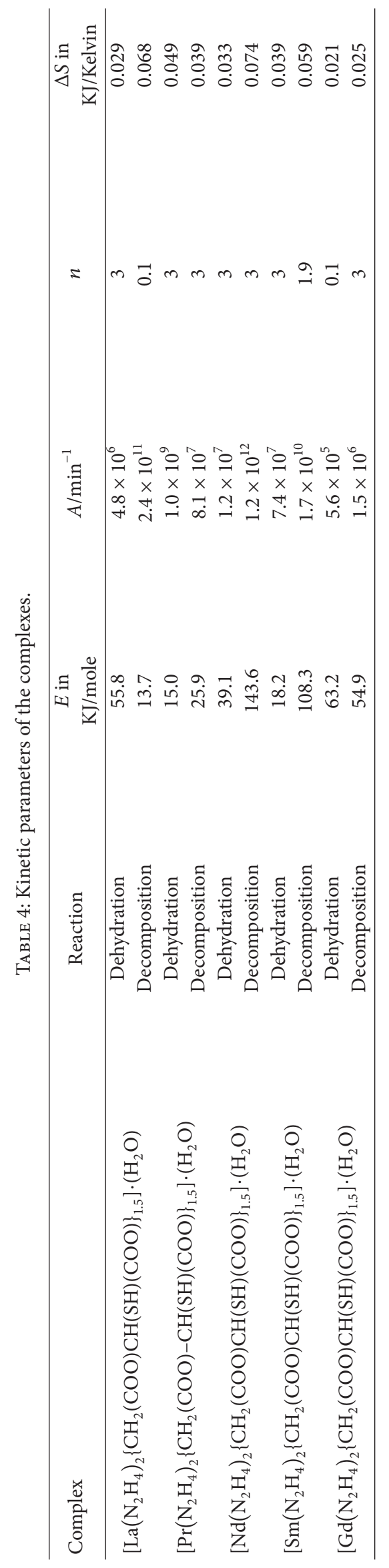




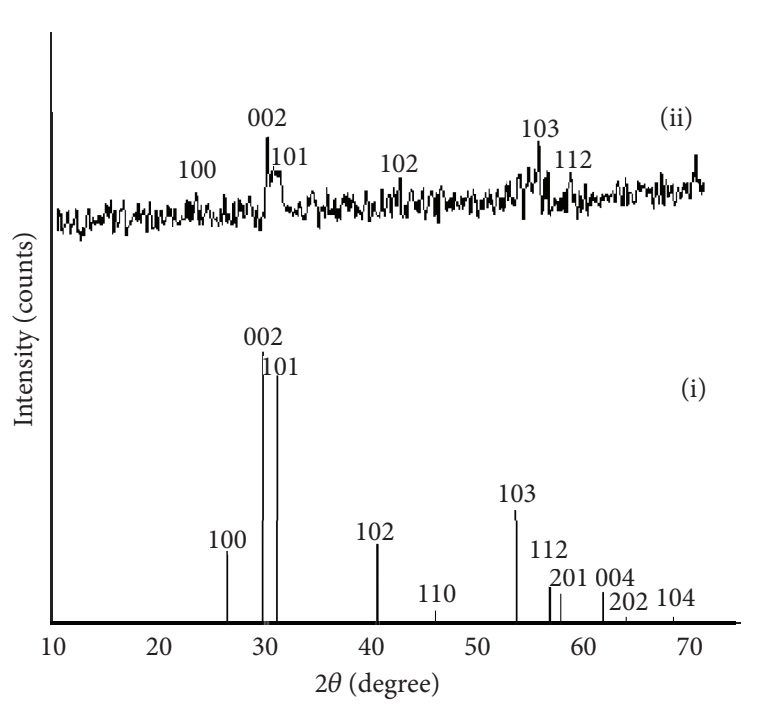

(a)

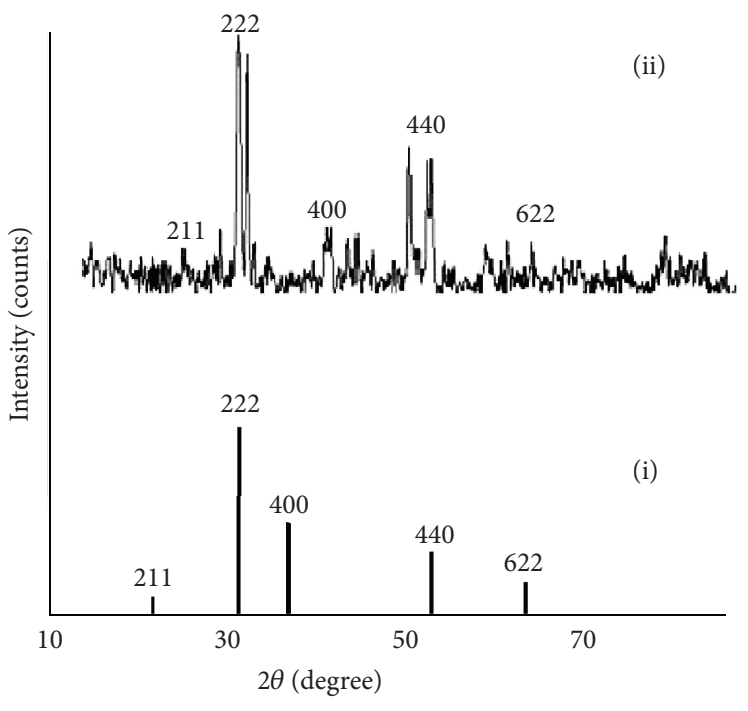

(b)

Figure 3
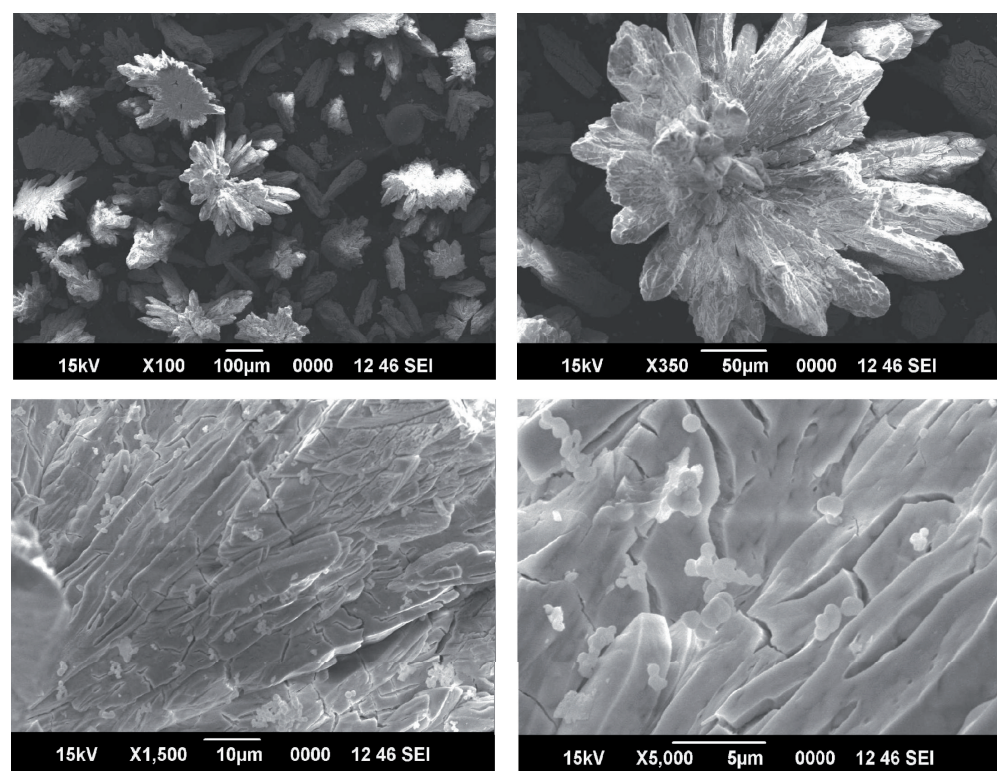

(a)
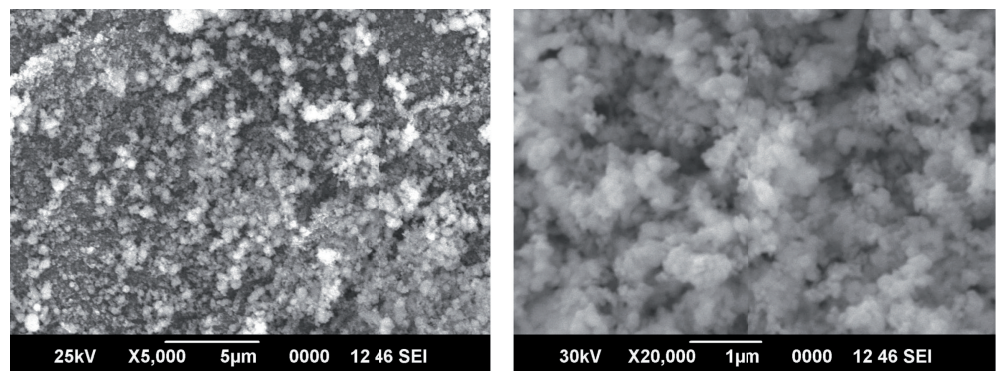

(b)

FIGURE 4 


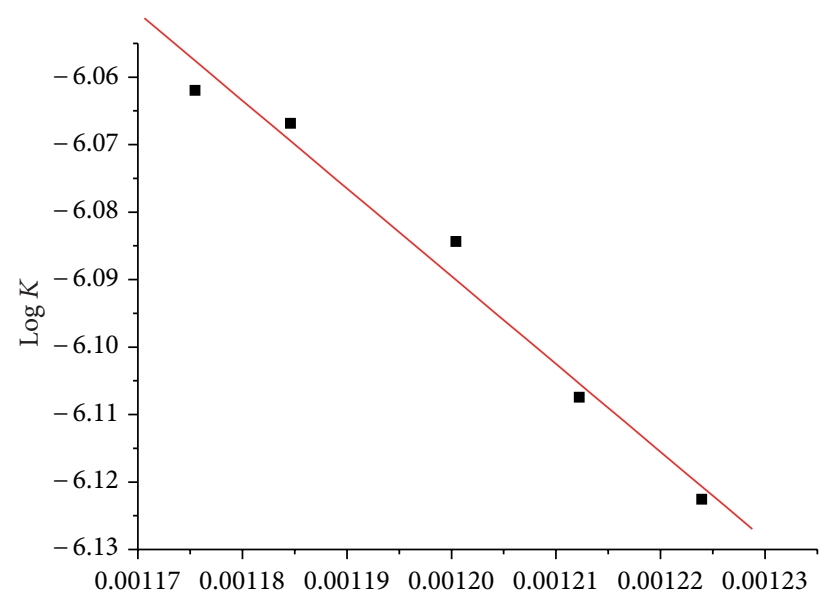

- B

Linear fit of data $1 \_B$

(a)

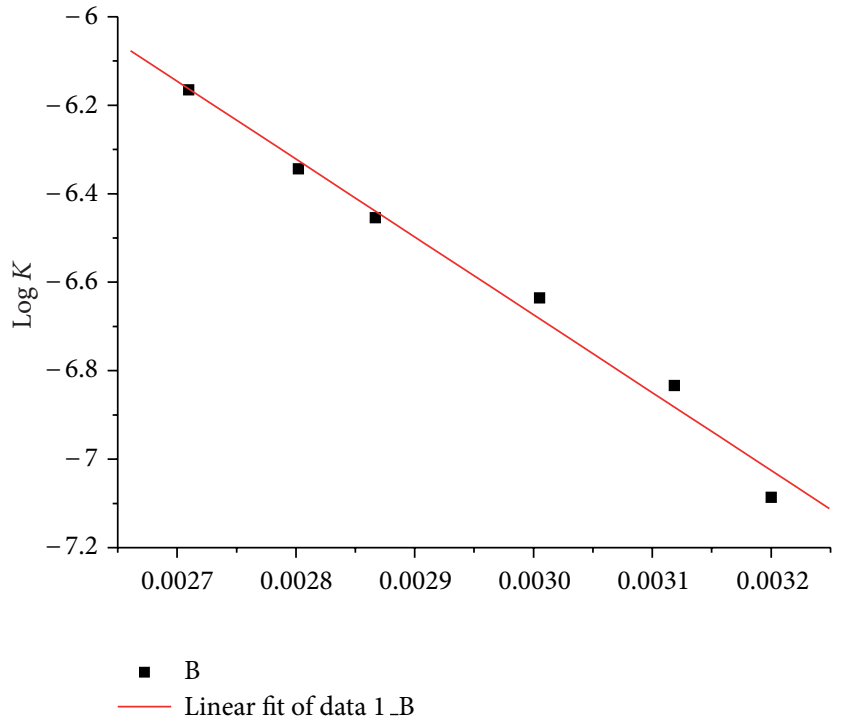

(b)

FiguRe 5

TABLE 5: X-ray diffraction of metal complexes (D spacing in $\AA$ units and intensity (Cps) in parentheses).

\begin{tabular}{lcccc}
\hline \multicolumn{5}{c}{$\left[\mathrm{Ln}\left(\mathrm{N}_{2} \mathrm{H}_{4}\right)_{2}\left\{\mathrm{CH}_{2}(\mathrm{COO}) \mathrm{CH}(\mathrm{SH})(\mathrm{COO})_{1.5}\right] \cdot\left(\mathrm{H}_{2} \mathrm{O}\right)\right.$} \\
$\mathrm{La}$ & $\mathrm{Pr}$ & $\mathrm{Nd}$ & $\mathrm{Sm}$ & $\mathrm{Gd}$ \\
\hline 9.0 & 9.6 & 8.9 & 9.7 & 8.9 \\
$(9.8)$ & $(9.1)$ & $(9.8)$ & $(9.2)$ & $(9.8)$ \\
8.3 & 8.9 & 8.3 & 8.4 & 5.7 \\
$(10.5)$ & $(9.8)$ & $(10.5)$ & $(10.4)$ & $(15.5)$ \\
4.5 & 4.5 & 4.5 & 4.6 & 4.6 \\
$(19.5)$ & $(19.6)$ & $(19.4)$ & $(19.1)$ & $(19.1)$ \\
4.0 & 4.0 & 4.1 & 4.1 & 4.2 \\
$(21.9)$ & $(21.8)$ & $(21.5)$ & $(21.6)$ & $(21.1)$ \\
3.9 & 3.9 & 3.9 & 3.9 & 3.2 \\
$(22.5)$ & $(22.5)$ & $(22.6)$ & $(22.6)$ & $(21.9)$ \\
3.5 & 3.5 & 3.5 & 3.6 & 3.0 \\
$(24.7)$ & $(24.8)$ & $(24.7)$ & $(24.5)$ & $(29.5)$ \\
2.8 & 3.2 & 3.2 & 3.2 & 2.8 \\
$(30.9)$ & $(27.2)$ & $(27.2)$ & $(27.5)$ & $(30.9)$ \\
\hline
\end{tabular}

The thermograms (Figure 2) reveal that the complexes start losing water first and then hydrazine up to $290^{\circ} \mathrm{C}$, showing endotherms in the range of $93^{\circ} \mathrm{C}$ to $105^{\circ} \mathrm{C}$ and broad exotherms in the range of $220-290^{\circ} \mathrm{C}$, respectively. Dehydration happening around $100^{\circ} \mathrm{C}$ indicates that water present in the complexes is not coordinated. Endotherm and exotherm suppress each other by mutual exchange of heat resulting in display of weaker peaks. This is a commonly observed phenomenon in case of decompositions of hydrazine complexes eliminating water and hydrazine simultaneously [21]. Then a continuous decomposition of hydrazine complexes from 290 to $650^{\circ} \mathrm{C}$ corresponding to the decomposition of the remaining compound in to oxide exhibiting exotherms at $309-325^{\circ} \mathrm{C}$ and $550-594^{\circ} \mathrm{C}$. No stable intermediate could be identified. The oxide formation is confirmed by comparing the XRD pattern of the residues. XRD patterns of final residues of $\mathrm{La}(\mathrm{III})$ and $\mathrm{Gd}(\mathrm{III})$ complexes are shown as representative examples in Figures 3(a)-3(b) with JCPDS patterns. The scheme of decomposition reactions are shown in (1).

The scheme of decomposition reactions are as follows:

$$
\begin{gathered}
{\left[\mathrm{Ln}\left(\mathrm{N}_{2} \mathrm{H}_{4}\right)_{2}\left\{\mathrm{CH}_{2}(\mathrm{COO}) \mathrm{CH}(\mathrm{SH})(\mathrm{COO})\right\}_{1.5}\right] \cdot\left(\mathrm{H}_{2} \mathrm{O}\right)} \\
\stackrel{93-290^{\circ} \mathrm{C}}{\mathrm{O} 2 \mathrm{~atm}} \operatorname{Ln}\left\{\mathrm{CH}_{2}(\mathrm{COO}) \mathrm{CH}(\mathrm{SH})(\mathrm{COO})\right\}_{1.5} \\
+\mathrm{H}_{2} \mathrm{O}+\mathrm{N}_{2} \mathrm{H}_{4} \\
\operatorname{Ln}\left\{\mathrm{CH}_{2}(\mathrm{COO}) \mathrm{CH}(\mathrm{SH})(\mathrm{COO})\right\}_{1.5}+(6.75) \mathrm{O}_{2} \\
\stackrel{550-594^{\circ} \mathrm{C}}{\longrightarrow} \frac{1}{2} \mathrm{Ln}_{2} \mathrm{O}_{3}+6 \mathrm{CO}_{2}+1.5 \mathrm{SO}_{2}+3 \mathrm{H}_{2} \mathrm{O} \\
\operatorname{Pr}\left\{\mathrm{CH}_{2}(\mathrm{COO}) \mathrm{CH}_{(\mathrm{SH})(\mathrm{COO})\}_{1.5}+(6.9) \mathrm{O}_{2}}\right. \\
\stackrel{563^{\circ} \mathrm{C}}{\longrightarrow} \frac{1}{6} \mathrm{Pr}_{6} \mathrm{O}_{11}+6 \mathrm{CO}_{2}+1.5 \mathrm{SO}_{2}+3 \mathrm{H}_{2} \mathrm{O}
\end{gathered}
$$

Ln $=$ La(III), Pr(III), Nd(III), Sm(III) \& Gd(III).

3.3. Scanning Electron Microscopy. The SEM images of the final products formed after the incineration of the complexes at their decomposition points, and sintering at the same temperature for about 3-4 hrs show that they are in nanoscale $(40-50 \mathrm{~nm})$. This fact is further substantiated by their XRD patterns using Scherrer's formula [22] $D=K \lambda / \beta \cos \theta$, where $\lambda$ is the $\mathrm{X}$-ray wavelength, $\beta$ is the full width of height 


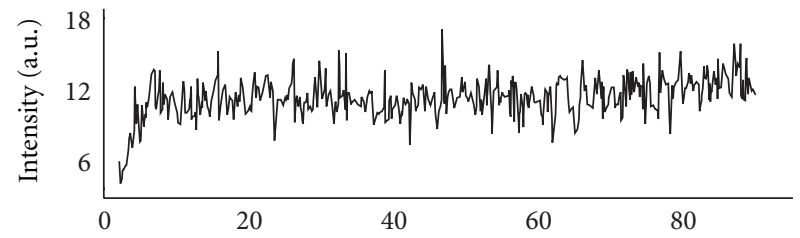

(e)

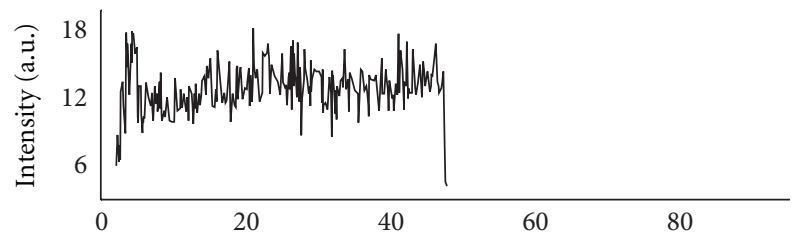

(d)

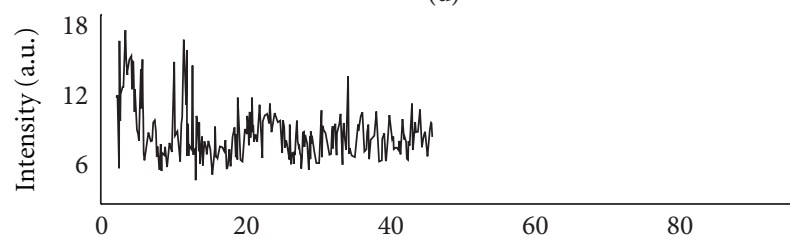

(c)

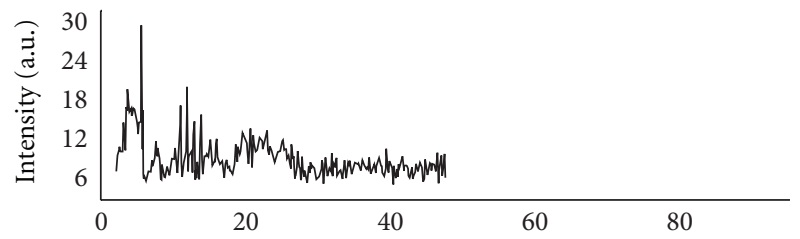

(b)

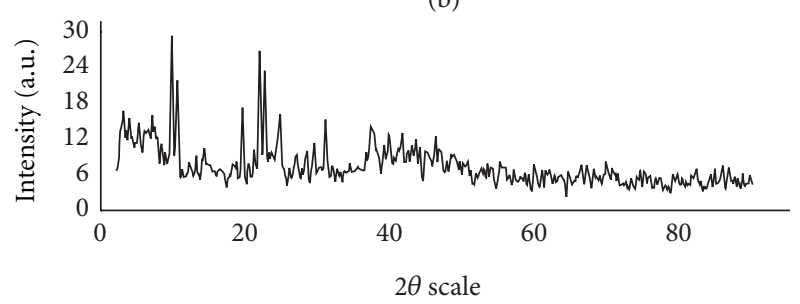

(a)

FIgURE 6: Comparison of XRD pattern of (a) $\left[\mathrm{La}\left(\mathrm{N}_{2} \mathrm{H}_{4}\right)_{2}\left\{\mathrm{CH}_{2}(\mathrm{COO}) \mathrm{CH}(\mathrm{SH})(\mathrm{COO})\right\}_{1.5}\right] \cdot\left(\mathrm{H}_{2} \mathrm{O}\right)$, (b) $\left[\mathrm{Pr}\left(\mathrm{N}_{2} \mathrm{H}_{4}\right)_{2}\left\{\mathrm{CH}_{2}(\mathrm{COO}) \mathrm{CH}(\mathrm{SH})(\mathrm{COO})\right\}_{1.5}\right] \cdot\left(\mathrm{H}_{2} \mathrm{O}\right)$, (c) $\left[\mathrm{Nd}\left(\mathrm{N}_{2} \mathrm{H}_{4}\right)_{2}\left\{\mathrm{CH}_{2}(\mathrm{COO}) \mathrm{CH}(\mathrm{SH})(\mathrm{COO})\right\}_{1.5}\right] \cdot\left(\mathrm{H}_{2} \mathrm{O}\right)$, (d) $\left[\mathrm{Sm}\left(\mathrm{N}_{2} \mathrm{H}_{4}\right)_{2}\left\{\mathrm{CH}_{2}(\mathrm{COO}) \mathrm{CH}(\mathrm{SH})(\mathrm{COO})\right\}_{1.5}\right] \cdot\left(\mathrm{H}_{2} \mathrm{O}\right)$, and (e) $\left[\mathrm{Gd}\left(\mathrm{N}_{2} \mathrm{H}_{4}\right)_{2}\left\{\mathrm{CH}_{2}(\mathrm{COO}) \mathrm{CH}(\mathrm{SH})(\mathrm{COO})\right\}_{1.5}\right] \cdot\left(\mathrm{H}_{2} \mathrm{O}\right)$.

maximum (FWHM) of a diffraction peak, $\theta$ is the diffraction angle, and $\mathrm{K}$ is Scherrer's constant of the order of 0.89 . The SEM images of final residue of $\mathrm{La}(\mathrm{III})$ and Gd(III) complexes are shown in Figures 4(a)-4(b) as representative examples. SEM image of $\mathrm{La}$ (III) and Gd(III) complexes residue show its nanosized clusters suggesting that the complexes may be used as a precursors for nanometal oxides [23].

3.4. UV-Visible Spectroscopy and Magnetic Susceptibility. The reflectance data of the UV-visible electronic spectra for $\operatorname{Pr}($ III), Nd(III), Sm(III), and Gd(III) complexes are summarized in Table 3. While comparing the spectral data [24] of complexes with those of aquo ion complexes, it is understood that all complexes show red shifts implying the complex formation. These magnetic moments from magnetic susceptibility measurements for $\operatorname{Pr}(\mathrm{III})$ and $\mathrm{Nd}$ (III) complexes are 4.10 and $3.40 \mathrm{BM}$, respectively. The variation of these values from that of free ions, 3.426 and 3.526, respectively, may be because of the influence of ligands on metal ions in complexes.

3.5. Kinetic Studies. Dehydration and decomposition kinetics of complexes were followed using TG. Their parameters have been computed using integral method developed by Coats and Redfern. The equation used for calculation of the $E$ and $A$ parameters is

$$
\log \left[1-\frac{(1-\alpha)^{n-1}}{(1-n) T^{2}}\right]=\log \frac{A R}{\varphi E}\left[1-\frac{2 R T}{E}\right]-\frac{E}{2.303 R T},
$$

where $\alpha$ is the fraction reacted in time $(t), T$ is temperature in $K, A$ is the preexponential factor in $\min ^{-1}, \varphi$ is the heating rate, $E$ is the activation energy in $\mathrm{KJ} / \mathrm{mole}$, and $R$ is the gas constant. Plotting $Y$ versus $1 / T$ gives a straight line; for a parameter, $n$, order of the reaction, where $Y=1-(1-\alpha)^{n-1} /(1-n) T^{2}$, the activation energy $E$ was calculated from the slope and the $A$ factor from the intercept [25]. Studies reveal that all the complexes follow the same mechanism of decomposition as inferred from their computed $E$ values. The activation energies for dehydration of the complexes are found to be almost similar in the range of 15.0-63.2 KJ/mole. Activation energies of decomposition of anhydrous complexes are found to be varying from 13.7 to $143.6 \mathrm{KJ} / \mathrm{mole}$. Table 4 shows the computed kinetic parameters for all the complexes, and the dehydration and decomposition kinetics for $\mathrm{La}(\mathrm{II})$ complex is shown in Figures 5(a)-5(b) as a representative example.

3.6. X-Ray Diffraction. The X-ray powder diffraction data of the complexes are summarized in Table 5. The X-ray powder diffraction data of the complexes with the formulation, $\left[\mathrm{Ln}\left(\mathrm{N}_{2} \mathrm{H}_{4}\right)_{2}\left\{\mathrm{CH}_{2}(\mathrm{COO}) \mathrm{CH}(\mathrm{SH})(\mathrm{COO})\right\}_{1.5}\right] \cdot\left(\mathrm{H}_{2} \mathrm{O}\right)$ where $\mathrm{Ln}=\mathrm{La}(\mathrm{III}), \operatorname{Pr}(\mathrm{III}), \mathrm{Nd}(\mathrm{III})$ show similarity among them, implying isomorphism. The XRD pattern of the complexes are shown in Figures 6(a)-6(e). Sm(III) and Gd(III) complexes could not be compared from their pattern showing widening of peaks with weak intensity. This may be because of the very small particle size.

\section{Conclusion}

The reaction of metal nitrate with mercaptosuccinic acid and hydrazine hydrate yields stable complexes of formula $\left[\mathrm{Ln}\left(\mathrm{N}_{2} \mathrm{H}_{4}\right)_{2}\left\{\left(\mathrm{CH}_{2}(\mathrm{COO}) \mathrm{CH}(\mathrm{SH})(\mathrm{COO})\right\}_{1.5}\right] \cdot\left(\mathrm{H}_{2} \mathrm{O}\right)\right.$, where $\mathrm{Ln}=\mathrm{La}(\mathrm{III}), \operatorname{Pr}(\mathrm{III}), \mathrm{Nd}(\mathrm{III}), \mathrm{Sm}(\mathrm{III})$, and $\mathrm{Gd}(\mathrm{III})$ at $\mathrm{pH}$ 5. Analytical data confirm their formulation. The IR spectroscopic data of complexes indicate the monodental coordination of carboxylic acid with metals, noninvolvement of sulfhydryl group in coordination and bidental bridging mode of hydrazine. 
All the complexes may be isomorphic due to their similarity in their XRD patterns. The complexes undergo thermal decomposition to metal oxide particles of nanosize. This is because of the evolution of gases, $\mathrm{N}_{2}, \mathrm{CO}_{2}, \mathrm{NO}_{2}$, and $\mathrm{SO}_{2}$ due to instantaneous oxidation of organic moiety and hydrazine in the complex in the temperature range $550-594^{\circ} \mathrm{C}$. Powder $\mathrm{XRD}$ and SEM images results of residual oxides confirm the nano ize. Hence, it is suggested that the complexes may be used as precursors of nano $\mathrm{La}_{2} \mathrm{O}_{3}$ and $\mathrm{Gd}_{2} \mathrm{O}_{3}$.

\section{References}

[1] L. F. Larkworthy and D. Sattari, "Some complexes of thiomalate with bivalent transition metal ions and gold (I)," Journal of Inorganic and Nuclear Chemistry, vol. 42, no. 4, pp. 551-559, 1979.

[2] P. R. Patil and V. Krishnan, "Thiomalates of alkaline earth metals," Journal of Inorganic and Nuclear Chemistry, vol. 41, no. 7, pp. 1069-1073, 1979.

[3] M. Filella, A. Izquierdo, and E. Casassas, "The binding of metal ions by mercaptoacids. I. Formation constants for the complexes of mercaptosuccinate with zinc(II), nickel(II), and hydrogen ions," Journal of Inorganic Biochemistry, vol. 28, no. 1, pp. 1-12, 1986.

[4] M. Cefola, A. S. Tompa, V. Celiano, and P. S. Gentile, "Coördination compounds. II. Trends in the stability of some rare earth chelates," Inorganic Chemistry, vol. 1, no. 2, pp. 290-293, 1961.

[5] B. R. Panchal and P. K. Bhattacharya, "Study in some heterochelates-I Zn(II) + nitrilotriacetic acid + mercapto acid systems," Journal of Inorganic and Nuclear Chemistry, vol. 34, no. 12, pp. 3932-3935, 1972.

[6] P. Ravindranathan and K. C. Patil, "Thermal reactivity of metal formate hydrazinates," Thermochimica Acta, vol. 71, no. 1-2, pp. 53-57, 1984.

[7] G. V. Mahesh and K. C. Patil, "Thermal reactivity of metal acetate hydrazinates," Thermochimica Acta, vol. 99, pp. 153-158, 1986.

[8] B. N. Sivasankar and S. Govindarajan, "studies on bis-hydrazine complexes of metal propionates and mixed-metal propionates," Zeitschrift fur Naturforschung, vol. 49, no. 7, pp. 950-954, 1994.

[9] B. N. Sivasankar and S. Govindarajan, "Tris-hydrazine metal glycinates and glycolates: preparation, spectral and thermal studies," Thermochimica Acta, vol. 244, pp. 235-242, 1994.

[10] K. Kuppusamy and S. Govindarajan, "Synthesis, spectral and thermal studies of some 3d-metal hydroxybenzoate hydrazinate complexes," Thermochimica Acta, vol. 274, no. 1-2, pp. 125-138, 1996.

[11] S. Vairam and S. Govindarajan, "Hydrazinium complexes of lanthanide and transition metal squarates," Polish Journal of Chemistry, vol. 80, no. 10, pp. 1601-1614, 2006.

[12] S. Vairam, T. Premkumar, and S. Govindarajan, "Trimellitate complexes of divalent transition metals with hydrazinium cation thermal and spectroscopic studies," Journal of Thermal Analysis and Calorimetry, vol. 100, no. 3, pp. 955-960, 2010.

[13] N. Arunadevi, "Studies on naphthoate, hydroxy naphthoate and naphthoxy acetate complexes of transition metals with hydrazine as co-ligand," [Ph.D. thesis], Anna University, Chennai, India, 2009.

[14] N. Arunadevi, S. Devipriya, and S. Vairam, "Hydrazinium metal 1- hydroxy-2-naphthoates-new precursors for metal oxides,"
International Journal of Engineering Science and Technology, vol. 3, no. 1, pp. 1-8, 2009.

[15] D. N. Sathyanarayana and D. Nicholls, "Vibrational spectra of transition metal complexes of hydrazine. Normal coordinate analyses of hydrazine and hydrazine-d4," Spectrochimica Acta Part A, vol. 34, no. 3, pp. 263-267, 1978.

[16] B. T. Heaton, C. Jacob, and P. Page, "Transition metal complexes containing hydrazine and substituted hydrazines," Coordination Chemistry Reviews, vol. 154, pp. 193-229, 1996.

[17] A. I. Vogel, A Textbook of Quantitative Inorganic Analysis Including Elementary Instrumental Analysis, The English Language Book Society and Longmans, Green Co, London, UK, 3rd edition, 1975.

[18] P. R. Patil and V. Krishnan, "Thiomalates of alkaline earth metals," Journal of Inorganic and Nuclear Chemistry, vol. 41, no. 7, pp. 1069-1073, 1979.

[19] E. W. Schmidt, Hydrazine and Its Derivatives-Preparation, Properties and Applications, Wiley Interscience, New York, NY, USA, 1984.

[20] K. Nakamoto, Infrared Spectra and Raman Spectra of Inorganic and Coordination Compounds, Wiley Interscience Co, New York, NY, USA, 6th edition, 2009.

[21] T. Premkumar and S. Govindarajan, "The chemistry of hydrazine derivatives-thermal behavior and characterisation of hydrazinium salts and metal hydrazine complexes of 4,5imidazoledicarboxylic acid," Thermochimica Acta, vol. 386, no. 1, pp. 35-42, 2002.

[22] G. Cao, Nano Structures and Nano Materials, Synthesis, Properties and Applications, Imperial College Press, London, UK, 2004.

[23] K. C. Patil, "Metal-hydrazine complexes as precursors to oxide materials," Journal of Chemical Sciences, vol. 96, no. 6, pp. 459-464, 1986.

[24] W. T. Carnall, P. R. Fields, and K. Rajnak, "Electronic energy levels of the trivalent lanthanide aquo ions. III. $\mathrm{Tb}^{3+}$, The Journal of Chemical Physics, vol. 49, no. 10, pp. 4412-4423, 1968.

[25] K. G. Mallikarjun, "Thermal decomposition kinetics of Ni(II) chelates of substituted chalcones," E-Journal of Chemistry, vol. 1, no. 2, pp. 105-109, 2004. 

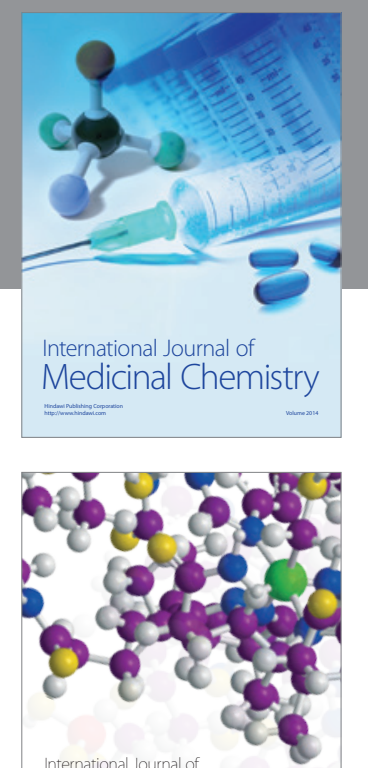

\section{Carbohydrate} Chemistry

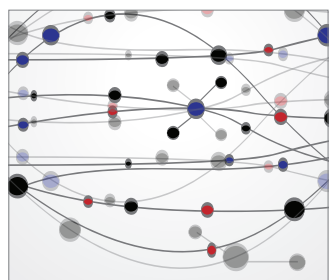

The Scientific World Journal
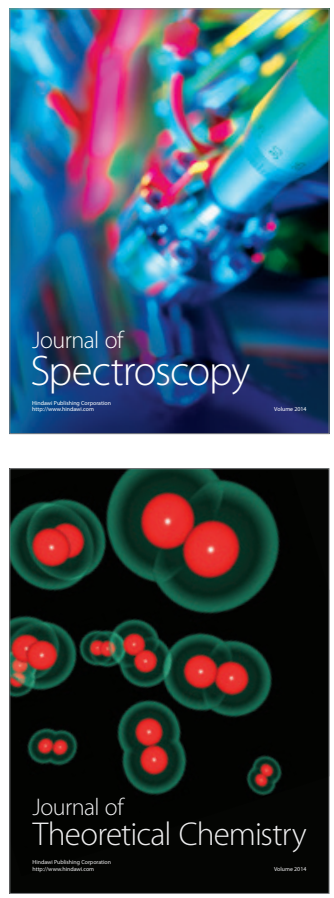
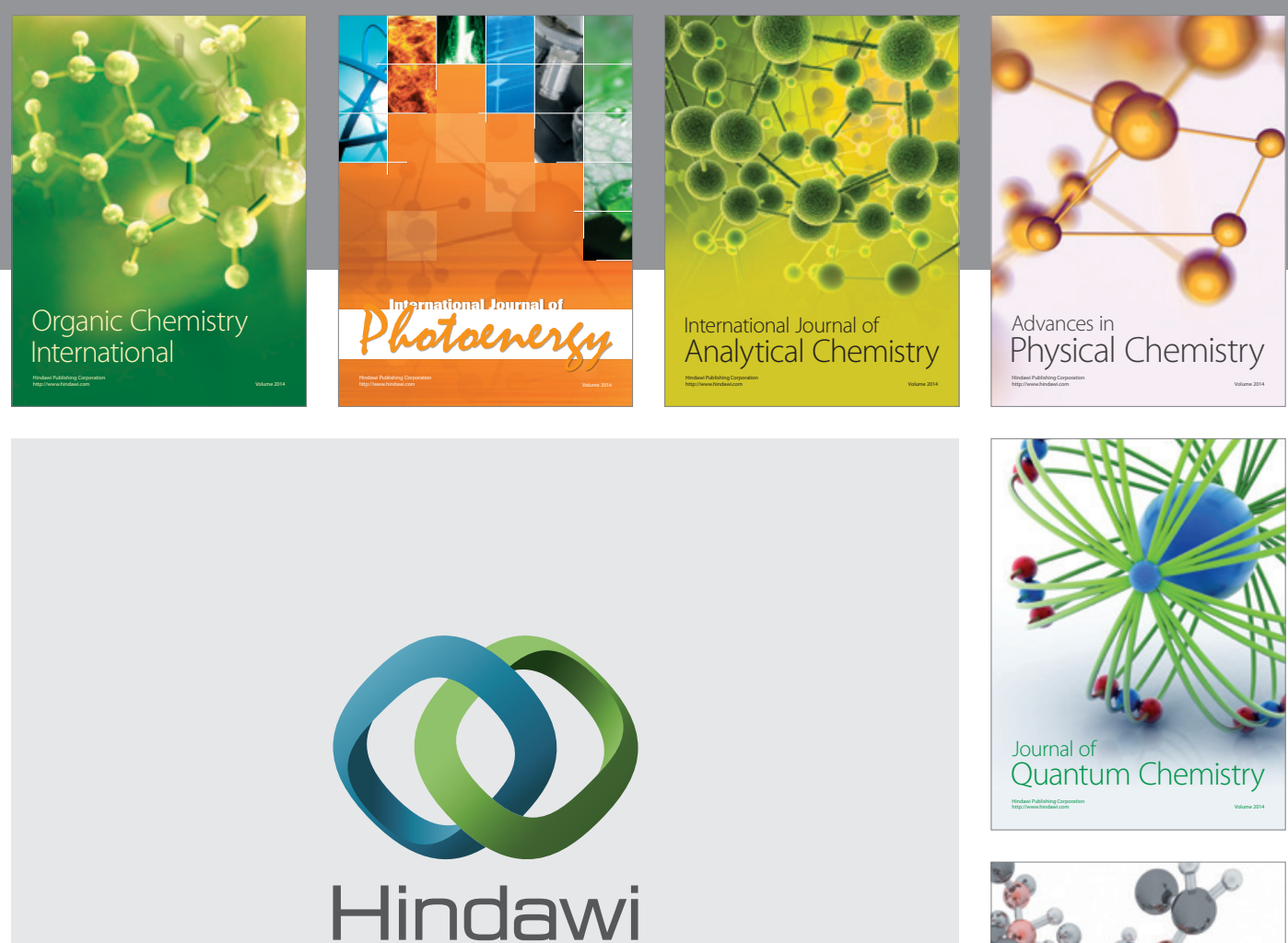

Submit your manuscripts at

http://www.hindawi.com

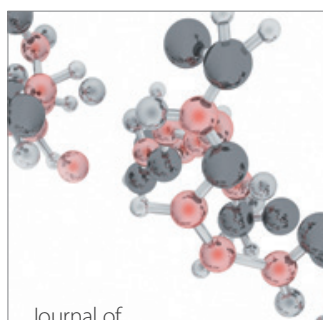

Analytical Methods

in Chemistry

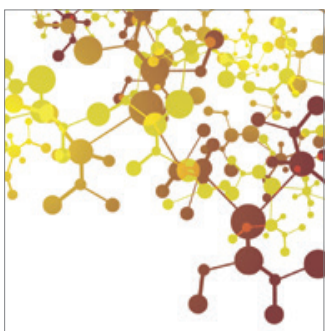

Journal of

Applied Chemistry

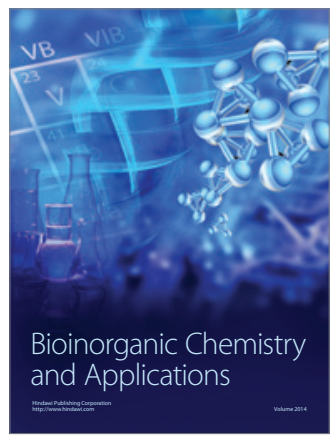

Inorganic Chemistry
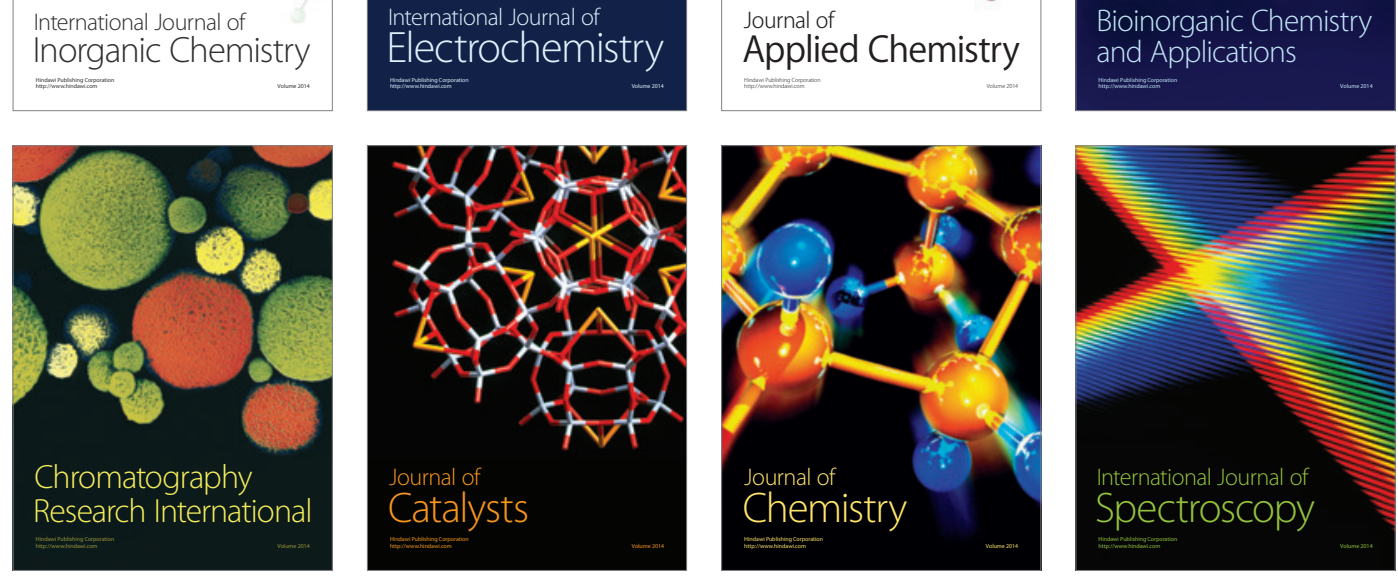